\title{
Growth and development of children in adolescent mother in Gunungkidul
}

\author{
Dewi Rokhanawati ${ }^{*}$, Rosmita Nuzuliana ${ }^{2}$ \\ ${ }^{1,2}$ Universitas Aisyiyah Yogyakarta 55292, Yogyakarta, Indonesia \\ 1'dewi dewirokhanawati@unisayogya.ac.id*, ${ }^{2}$ rosmitanz@unisayogya.ac.id* \\ *corresponding author
}

Submission date: 19 Agustus 2021, Receipt date: 8 Oktober 2021, Publication date: 1 November 2021

\begin{abstract}
Adolescent mothers with poor knowledge and skills in parenting will adversely affect the development of children. In 2018, children under five in Gunungkidul experienced developmental delays (1.05\%). This study was descriptive observation with 30 respondents of adolescent mothers under 21 years of age. Questionnaires were used to complete the data. Other tools used were infantometer, weight scales, Denver II Form, Z Score table. The results show that predominant respondents have low education (66.7\%) and the majority are housewives. The weight of the children is in accordance to their age, the majority of the height is normal, but $56.7 \%$ of children experience developmental delays.
\end{abstract}

Keywords: adolescent mothers, growth, development, children

\section{INTRODUCTION}

Superior human resources are not created at one time but require a long process based on the developmental stages that have been experienced. The first 1000 days of life is the most dominant developmental stage in determining the quality of human resources started from the pregnancy age to 2 years after birth. Early age is a golden period of child development. In this stage, children experience a very rapid developmental spike. The data stated that $30.8 \%$ of children experienced stunting with the description of children with very short bodies (11.5\%) and short bodies (19.3\%). As many as $31.59 \%$ of children aged 0-17 years experienced health complaints, and $15.89 \%$ of them were sick (experienced health complaints and interfered with daily activities) (Unicef Indonesia, 2020). In the Special Region of Yogyakarta, the prevalence of stunting data was 10.69 in 2019. Gunungkidul Regency reached the highest prevalence of stunting under five (17.94) and the lowest was Bantul Regency (7.73). The data shows that the prevalence of very short children in DIY is lower compared to Riskesdas in 2018 (21.4\%) (Dinkes DIY, 2020).

Meanwhile, data on child development states that around 250 million children under five years are at risk of not being able to achieve maximum development, and more than 200 million children under five worldwide are estimated to experience cognitive and social-emotional development disorders (Unicef Indonesia, 2020). In Indonesia, based on data from the Indonesian Ministry of Health (2016), there are 42.5\% of children under five experience developmental disorders in personal social aspects and $38.11 \%$ of gross motor skills. Based on the data of Dinas Kesehatan Kab. Gunungkidul, (2018), there are around $1.05 \%$ of children under five who experience developmental disorders in the form of gross motion, fine motion, language, and personal-social. 
Parents play a key role in the child development process. According to Kitano et al. (2016), getting married at young age has an impact on knowledge and skills in parenting. Wulandari, (2017) states that the growth of children is directly influenced by birth weight and family income, while child development is influenced by marriage age, family stimulation, and birth weight. Weight at birth can affect the development of children because children with LBW (low birth weight) are at risk of developmental problems (UNICEF, 2020).

The data states that marriages at the age of 10-17 years are $0.7 \%$ dominated by the age of 16 and 17 years are 72\% including married and divorced (Kementerian Pemberdayaan Perempuan dan Perlindungan Anak, 2019; Badan Pusat Statistik, 2019). About 16 million teenage girls between the ages of 15 - 19 give birth each year. Babies born to adolescent mothers are $11 \%$ worldwide which $95 \%$ occurs in developing countries (Muslimat NU, 2020).

In Indonesia, there are $11 \%$ of teenagers married at the age of 15 years and $35 \%$ married at the age of 18 years (Badan Pusat Statistik, 2016; UNICEF, 2016). Based on data from DIY Provincial Health Office, there are three districts with thousands of young marriage cases: Bantul, Gunungkidul, and Sleman districts. In 2016, the highest cases were in Gunungkidul Regency, which was 1,395 cases (Dinas Kesehatan Provinsi Daerah Istimewa Yogyakarta, 2017). Data on childbirth for adolescents aged 10-18 years in Gunungkidul in 2017 were 257 cases and 204 in 2018 (Dinas Kesehatan Kabupaten Gunungkidul, 2018). Based on those exposures, researchers are interested in examining the growth and development of children under five born to adolescent mothers in three Public Health Centers in Gunungkidul Regency.

\section{RESEARCH METHODS}

This research was descriptive observational research. The population in the study were adolescent mothers aged under 21 years who had children under five. The study was conducted in 3 Public Health Centers: Semanu 1 Health Center, Ponjong 1 Health Center, and Saptosari Health Center with a total of 34 people. The samples used in this study were 30 respondents. The sample in this study were adolescent mothers aged under 21 years who had children under five. This study used Total Sampling techniques. The samples were collected based on inclusion criteria: (1) mothers willing to be research respondents, (2) mothers aged under 21 years, (3) mothers having children under five, (4) living in the areas of Semanu 1, Ponjong 1 and Saptosari Health Centers.

This study used a questionnaire as an instrument to compile the information of the research subjects. In addition, researchers used a weighing device (with a new battery to get the appropriate results), a microtoice (body length measurement) used for children aged more than 24 months, and an infantometer for children aged under 24 months. This research was approved by the UNS Health Research Ethics Committee, Ethical Eligibility Statement No 032/UN27.06.6.1/KEPK/EC/2020.

The collected data were the primary data. The researcher collaborated with the Public Health Center, village government, and health cadres in the process of collecting data on the growth and development of children under five. The analysis was carried out 
univariately on the variables of growth and development of children under five. This univariate analysis produced data of frequency and percentage distributions on the growth and development variables of children under five.

\section{RESULTS AND DISCUSSION}

Semanu 1 Health Center, Ponjong 1 Health Center, and Saptosari Health Center are located in the Gunungkidul area. These Public Health Centers have a very wide and hilly area coverage. Monitoring activities for growth and development of children are carried out in these Public Health Centers during the pandemic through posyandu with the concept of new normal. This concept means that every posyandu activity must apply health protocols such as wearing the mask, washing hands before the posyandu, making time schedules for mother and child arrivals according to the agreed hours, implementating five tables limited by time. Monitoring progress is not always carried out by these Public Health Centers at every posyandu. The form used in monitoring progress is the Denver II form. The complete recording and reporting of monitoring results are written in KIA book and posyandu register book. The data is then reported to the health center (Table 1).

Table 1. Characteristics of Respondents

\begin{tabular}{lcc}
\hline & $\mathrm{f}$ & $\%$ \\
\hline AGE (years) & 3 & 10.0 \\
18 & 11 & 36.7 \\
19 & 13 & 43.3 \\
20 & 3 & 10.0 \\
21 & & \\
Education Level & 5 & 16.7 \\
Elementary school & 20 & 66.7 \\
Junior high school & 5 & 16.7 \\
Senior high school & & \\
Type of Work & 26 & 86.7 \\
Not working & 4 & 13.3 \\
Working & & \\
\hline
\end{tabular}

Table 1 shows that most respondents are aged 20 years (43.3\%), a junior high school education level (66.7\%) and the majority are not working / as housewives. The results of the identification state that the husbands of the respondents predominantly work and some of them work as laborers with the predominant education of junior high school. 
Table 2. Monitoring Results of Respondents' Child Growth

\begin{tabular}{lcc}
\hline & $\mathrm{f}$ & $\%$ \\
\hline Gender & & \\
Male & 14 & 46.7 \\
Female & 16 & 53.3 \\
Growth by BW/U & & \\
More & 1 & 3.3 \\
Less & 3 & 10.0 \\
Good & 26 & 86.7 \\
& & \\
Growth by PB/U & & \\
Very Short & 1 & 3.3 \\
Short & 8 & 26.7 \\
Normal & 21 & 70.0 \\
Child development & & \\
Suspect & & \\
Normal & 17 & 56.7 \\
\hline
\end{tabular}

The results of growth and development monitoring of respondents' children show that predominant gender of the children is female, the weight growth is good (W/U) with normal height (PB/U). Table 2 depicts the growth of children born to adolescent mothers. The predominant children's growth is good based on the result of the weight monitoring chart adjusted for age. The predominant height is normal. However, there are $3.3 \%$ of overweight children, $10 \%$ of underweight children of their age, $26.7 \%$ of short children, and $3.3 \%$ of very short children. Problems with weight and height are caused by several factors. The predominant factor is caused by eating patterns. Food plays an important role in the growth and development of children which children's need is different from adults'.

Food for children is essentially needed in the process of growth and development, especially during the golden period of child development (golden age period). An important aspect of food that needs to be considered is food safety which includes free food of chemical physical and biological hazards (Soetjiningsih \& Ranuh, 2013). Nutrients consumed by children will affect their nutritional status. Adequate nutrition becomes one of the factors in achieving the child's maximum growth and development. Malnutrition can cause growth and development disorders, alter brain structure and function. Malnutrition at the age under 2 years will cause the brain cells to decrease by $15-20 \%$ so that children only have $80-85 \%$ brain quality (Gunawan et al., 2011).

The need and fulfillment of food depend on the caregiver who in this case is the adolescent mother. The low level of education and the economics of the community is the reason for the limited application of feeding patterns for children under three years of age. The role of mothers in fulfilling nutritious food is very important in supporting optimal child development. In addition, mothers' readiness in caring for children to achieve optimal growth and development is important, especially in their early life (Yunarsih and Quyumi, 2013). 
Carrying out the role of a mother at a young age is not easy. A woman who has entered the stage of marriage must prepare herself for the process of pregnancy and childbirth. The lack of knowledge in parenting is a factor causing the difficulty in child care. Thus, support from social and emotional environments is needed to help mothers be more ready to take care of their children (Erfina et al., 2019). Agustiningrum and Rokhanawati (2016) support the idea stunting that the mothers' knowledge about poor stunting is correlated with the incidence of stunting in children.

The problems occurred in malnourished children are not only in the thin or fat body postures but it can also have an impact in children's cognitive. Children who are malnourished in toddler but experience cath-up in childhood will have a higher intellectual level than children who do not experience cath-up in their growth (Crookston et al., 2010). The low cognitive condition of children will result in low children's achievements and low-quality human resources (Dasman, 2019). On the other hand, children with poor nutritional status are more susceptible to degenerative diseases. This happens because children experience problems with the development of the insulin and glucagon hormonal systems in the pancreas which regulate glucose balance and metabolism. Therefore, in adulthood, children will experience an excess of calorie intake, easy-disturbed blood sugar balance, and easy-body fat tissue formation (lipogenesis). This poor nutritional condition status will play a role in the double increase of the nutritional burden to the increase of chronic disease. Those problems will lead to low quality of human resources if not given sufficient intervention (Dasman, 2019).

Adiningsih, Rifqi, and Muthmainnah, (2018) found that there was a relationship between poor nutritional status especially stunting, and delayed tooth growth. There was a significant difference between children whose teeth had not grown and the first teething age in the two groups $(\mathrm{p}<0.05)$. Tooth growth starting from the gums correlates with the degree of nutritional status (Flores-Mir, Mauricio, Orellana, \& Major, 2005). The frequency of diarrhea that often attacks stunted children causes the intake of calcium and other minerals to decrease so that the growth of children is increasingly disrupted.

The stunting of children under five found in this study is probably due to parental income. The income of the family is in line with the provision of a safe and clean environment, adequate clean water, and adequate sanitation. The environment with clean drinking water, good sanitation, and healthy home conditions with closed toilets will reduce the incidence of stunting in children. Conversely, poor sanitation will reduce food safety that can increase the risk of infection (Taguri et al., 2015). This infectious disease interferes with the absorption of nutrients in the child's digestive process. This condition will result in low children's weight. Weight loss accompanied by inadequate nutritional intake will cause chronic nutritional problems that will lead to stunting (Sekunda et al., 2018).

Table 2 shows that the predominant development of the respondent's children is the suspect or there is a possibility of development delay. Based on the assessment of identification results on the Denver II sheet, the most delay occurs in the language sector. Campbell et al. (2003) in Nuzuliana, Ismail, and Hikmah (2016) explains that the mother's education level affects language development in children. In this study, the predominant education of the parents is at the elementary/junior high school level. Mothers with low 
education produce 2.86 times children with language delays. This is because the low level of education has an impact on the lack of vocabulary or combination of words directed to children. The low level of education results in a lack of maternal perceptions regarding health care and inadequate nutrition. In addition, mental health, abuse, and parental neglect are the main risk factors for children's language development. The cumulative environmental risks are strongly associated with an increased incidence of behavioral, socioemotional, and language problems (Gurgel et al., 2014).

Gurgel et al., (2014) mention other risk factors that cause delays in children are family dynamics (children's interactions with parents and the closest social environment), biological factors (premature birth, brain injury, persistent otitis media, and heart surgery), and type of male sex in children. The stimulation factor has a significant relationship with child development. Stimulation given by parents from the early child's birth strongly supports optimal development.

Leroy and Frongillo (2019) in their literature review explain that children who have a smaller body size will reduce motor activity that limits the children's ability to explore and access stimulation of language, socioemotional and cognitive development. Delay in motor development is more likely due to body balance, muscle strength, and lack of endurance, as well as myelination factors. Myelination is the process of myelin formation in the nerves of the brain. Myelin is very important in normal motor function (e.g. movements such as walking), sensory function (e.g. hearing, seeing, or feeling pain sensations), and cognition (e.g. acquiring and recalling knowledge). This study found that a small body size did not mean short stature. Children with short stature will experience limitations in gross motor skills, language, and cognition if the process of body balance, endurance, and myelination are disturbed.

\section{CONCLUSION}

The growth of the children is good based on the result of the weight monitoring chart adjusted for age. The predominant height is normal. However, there are $3.3 \%$ of overweight children, $10 \%$ of underweight children for their age, $26.7 \%$ of short children, and $3.3 \%$ of very short children. Child development is monitored using Denver II with the result that 17 children are suspected $(56.7 \%)$ or there is a possibility of delay in their development.

From this research, it is expected that unmarried adolescents will postpone the age of marriage. By delaying the age of marriage, adolescents will be able to prepare themselves better physically, psychologically and have adequate knowledge to have children. Children born to mothers who are physically and psychologically ready for growth and development are much more optimal. It is also hoped that the Public Health Center will pay more attention to the data collection process for adolescent mothers. With accurate data, Public Health Center will be able to intervene more easily in the deviations of the growth and development of children born to adolescent mothers. The Public Health Centers can also make a schedule of development monitoring activities in the targeted area in collaboration with the health cadres. 


\section{REFERENCES}

Adiningsih, S., Rifqi, M. A., \& Muthmainnah. (2018). Pengaruh Pemberian Biskuit Terhadap Perubahan Berat Badan Balita Stunting Usia 6-17 Bulan. Widyakarya Nasional Pangan Dan Gizi (WNPG) “Percepatan Penurunan Stunting Melalui Revitalisasi Ketahanan Pangan Dan Gizi Dalam Rangka Mencapai Tujuan Pembangunan Berkelanjutan."

Agustiningrum, T dan Rokhanawati, D. (2016). Hubungan Karakteristik Ibu Dengan Kejadian Stunting pada Balita Usia 24-59 Bulan Di Wilayah Kerja Puskesmas Wonosari I

Badan Pusat Statistik, \& UNICEF. (2016). Analisis Data Perkawinan Usia Anak di Indonesia. Badan Pusat Statistik.

Crookston, B. T., Penny, M. E., Alder, S. C., Dickerson, T. T., Merrill, R. M., Stanford, J. B., Porucznik, C. A., \& Dearden, K. A. (2010). Children Who Recover from Early Stunting and Children Who Are Not Stunted Demonstrate Similar Levels of Cognition 1 , 2. The Journal of Nutrition, 15, 1996-2001. https://doi.org/10.3945/jn.109.118927.)

Dasman, H. (2019). Empat dampak stunting bagi anak dan negara Indonesia. The Conversation (Disipln Ilmiah, Gaya Jurnalistik), 22-24. http://repo.unand.ac.id/21312/1/Empat dampak stunting bagi anak dan negara Indonesia.pdf

Dinas Kesehatan Kab. Gunungkidul. (2018). Profil Kesehatan Dinas Kesehatan Kabupaten Gunungkidul Tahun 2017. Dinas Kesehatan Kabupaten Gunungkidul.

Dinas Kesehatan Provinsi Daerah Istimewa Yogyakarta. (2017). Data Pernikahan Dini Provinsi D I Yogyakarta tahun 2014-2016. Dinas Kesehatan Daaerah Istimewa yogyakarta.

Dinkes DIY. (2020). Profil Kesehatan Daerah Istimewa Yogykarta Tahun 2019. Dinas Kesehatan Daerah Istimewa Yogyakarta. https://webcache.googleusercontent.com/search?q=cache:6QQO4BH986AJ:https:// www.dinkes.jogjaprov.go.id/+\&cd=1\&hl=id\&ct=clnk\&gl=id\&client=firefox-b-d

Erfina, E., Widyawati, W., McKenna, L., Reisenhofer, S., \& Ismail, D. (2019). Adolescent mothers' experiences of the transition to motherhood: An integrative review. International Journal of Nursing Sciences, 6(2), 221-228. https://doi.org/10.1016/j.ijnss.2019.03.013

Gunawan, G., Fadlyana, E., \& Rusmil, K. (2011). Hubungan Status Gizi dan Perkembangan anak Usia 1-2 tahun. 13(2), 142-146. http://saripediatri.idai.or.id/pdfile/13-2-10.pdf

Gurgel, L. G., Vidor, D. C. G. M., Joly, M. C. R. A., \& Reppold, C. T. (2014). Risk factors for proper oral language development in children: a systematic literature review. CoDAS, 26(5), 350-356. https://doi.org/10.1590/2317-1782/20142014070

Kementerian Pemberdayaan Perempuan dan Perlindungan Anak dan Badan Pusat Statistik. (2019). Profil Anak Indonesia Tahun 2019. Kementerian Pemerdayaan 
Perempuan Dan Perlindngan Anak (KPPPA), 378. https://www.kemenpppa.go.id/lib/uploads/list/15242-profil-anak-indonesia_2019.pdf

Kitano, N., Nomura, K., Kido, M., Murakami, K., Ohkubo, T., Ueno, M., \& Sugimoto, M. (2016). Combined effects of maternal age and parity on successful initiation of exclusive breastfeeding. Preventive Medicine Reports, 3, 121-126. https://doi.org/10.1016/j.pmedr.2015.12.010

Leroy, J. L., \& Frongillo, E. A. (2019). Perspective : What Does Stunting Really Mean? A Critical Review of the Evidence. 196-204.

Muslimat NU. (2020). Manajemen Kebersihan Menstruasi dan Pencegahan Perkawinan Anak (H. Umniati (ed.)). Pimpunan Pusat Muslimat NU dan UNICEF Indonesia. https://www.pma2020.org/sites/default/files/IDR2-MHM brief-v1-Bahasa Indonesian-2017-05-03.pdf

Nuzuliana, R., Ismail, D., \& Hikmah. (2016). Hubungan Status Sosial Ekonomi dengan Perkembangan Batita. Jurnal Kebidanan Dan Keperawatan, 12(2), 109-117. https://ejournal.unisayogya.ac.id/ejournal/index.php/jkk/article/download/303/149

Sekunda, V., Tandang, Y., Adianta, I. K. A., \& Nuryanto, I. K. (2018). Hubungan ASI Esklusif dan Riwayat Penyakit Infeksi dengan Kejadian Stunting pada Balita di Wilayah Puskesmas Wae Nakeng. Sekolah TInggi Ilmu Kesehatan Bali.

Soetjiningsih, \& Ranuh, G. (2013). Tumbuh kembang Anak. EGC.

Taguri, A. El, Betilmal, I., Mahmud, S. M., Ahmed, A. M., Goulet, O., Galan, P., \& Hercberg, S. (2015). Risk factors for stunting among under-fives in Libya. Public Health Nutrition, 12(8), 1141-1149. https://doi.org/10.1017/S1368980008003716

UNICEF. (2020). Laporan Tahunan 2020 Indonesia. 1, 7-8.

Unicef Indonesia. (2020). Analisis Perkembangan Anak Usia Dini Indonesia 2018 Integrasi Susenas dan Riskesdas 2018 (Vol. 148). Badan Pusat Statistik.

Wulandari, U. R. (2017). Epidemiologi Sepanjang Hayat Faktor yang Mempengaruhi Pertumbuhan dan Perkembangan Anak Batita Dari Ibu yang Menikah Usia Dini di Kota Kediri. Sebelas Maret.

Yunarsih \& Quyumi. (2013). Pengaruh Stimulasi Tumbuh Kembang Ibu yang Menikah Usia Muda Terhadap Pertumbuhan dan Perkembangan Anak Usia di Bawah Lima Tahun (Balita) The Effect of the Young Age Marriage Mother stimulating growth on the Growth and Development of Children Under the Ag. Jurnal Ilmu Kesehatan, 2(2303-1433), 83-88. 